\title{
WIDE HOST RANGE PLASMID PROBE FOR THE HETEROLOGOUS TRANSMISSION OF Escherichia coli lac GENES.
}

\author{
(Sonda plasmidial de amplio rango de hospedero para la transmisión \\ heteróloga de los genes lac de Escherichia coli)
}

\author{
James Robeson, E. Llorens \& S.V. Godoy \\ Laboratorio de Genética Bacteriana \\ Instituto de Biología, Universidad Católica de Valparaíso \\ Casilla 4059, Valparaíso, Chile
}

Palabras clave: Clonación in vivo, pULB113, genes lac de $\boldsymbol{E}$.coli, transmisión horizontal de genes, bacterias marinas Key words: In vivo cloning, pULB113, E.coli lac genes, horizontal gene transfer, marine bacteria.

\section{SUMMARY}

The lac operon of Escherichia coli is a genetic system proven useful in the elucidation of basic principles of genetic variation and expression and in microbial strain construction for applied purposes. In this context, and using the in vivo cloning vehicle pULB113 (IncPa) we derived the corresponding wide host range plasmid pUCV 3, containing the $\boldsymbol{E}$. coli lac genes, which can now be delivered with ease to all microorganisms capable of incorporating replicons of the IncPa incompatibility group. In our experiments, pUCV3 was transmitted to representative marine bacteria and to the gliding, soil bacterium Cytophaga johnsonae. These microorganisms showed regulated expression of the heterologous lac system. Thus, pUCV3 could be used as a probe to evaluate behavior of the lac operon in varied, microbial genetic backgrounds.

\section{INTRODUCTION}

The genes for lactose utilization from Escherichia coli; have gathered a long standing interest, being therefore, the subject of a number of studies pertaining to both basic and applied research. Undoubtly, of prime relevance are the investigations of Jacob \& Monod (1961), based on the use of various mutations in the $\boldsymbol{E}$. coli lac region in conjunction with F'lac factors. These inquiries, marked by the analyses of haploid and merodiploid strains for the $\boldsymbol{E}$. coli lac genes, finally led to the definition of negative

\section{RESUMEN}

El operon lac de Escherichia coli, es un sistema genético que ha sido útil para elucidar principios básicos de variación y expresión genética y para la construcción de cepas microbianas de proyección industrial. En este contexto, hemos derivado por clonación in vivo, un plasmidio de amplio rango de hospedero ( $p U C V 3$ ), que contiene los genes lac de $\boldsymbol{E}$. coli, los cuales pueden ser ahora transmitidos con facilidad a todos los microorganismos capaces de incorporar replicones IncPa, grupo de compatibilidad al que pertenece pUCV3. Como ejemplo este plasmidio fue transmitido a bacterias marinas y a Cytophaga johnsonae, microorganismos en los cuales se apreció la expresión regulada del sistema lac. En consecuencia, $p U C V / 3$ puede ser usado como sonda para evaluar el comportamiento del operón lac en variados transfondos genéticos microbianos.

control of gene expression in a coordinately regulated set of genes: the lactose operon.

The lac system has also proven to be useful in addressing crucial issues contingent to the process of mutation. It has been a valuable tool to elucidate principles of both spontaneous and mutagen-induced mutation in bacteria (Eisenstadt, 1987) and in eukaryotic cells, into which tha lac genes are incorporated by means of appropriate shuttle vectors (Calos et al.,1983).

In a similar vein, the formation of papillae due to 
reversion of $l a c Z$ mutations, has been a fruitful analytical approach in the identification of mutator alleles (Nghiem et al., 1988). In addition, the lac system has been widely used to investigate non-sense suppression (Miller \& Albertini, 1983; Kleina etal., 1990) and to gain insight into the mobility of transposable genetic elements, through the analyses of lac segregation patterns (Bender \& Kleckner, 1986).

On the other hand, the concept of adaptive mutation in bacteria originated in studies on the pattern of reversion of a lacZam mutation under non-lethal selective conditions (Cairns et al., 1988). These observations have triggered a substantial amount of controversy (for a review see Sniegowsky \& Lenski, 1995) and continue to motivate experiments using the lac system (Galitski \& Roth, 1996), aimed at testing one of the basic tenets of evolutionary theory, namely that genetic variation precedes adaptation.

Certainly, one of the most important applications of the E.coli lac genes has been the use of genetic fusions between these genes and other target genetic units, with the purpose of monitoring the expression of genes lacking an easily assayable phenotype by means of the $\beta$ galactosidase activity coded by the fused $\operatorname{lac} Z$ gene, that acts as a reporter gene informing on the expression of the target gene (for a review see Slauch \& Silhavy, 1991).

Further practical applications of the lac system have used $\beta$-galactosidase activity to monitor individual, viable non-culturable cells of E.coli and Salmonella enteritidis by means of fluorescence microscopy (Nwoguh et al., 1995) and non-culturable coliforms in marine waters (Davies et al., 1995).

Finally, the $\boldsymbol{E}$. coli lac genes have been used as a substrate for the construction of lactose-utilizing, genetically engineered strains of Xanthomonas campestris, a bacterium that is naturally unable to use lactose as sole source of carbon. Nevertheless, $\boldsymbol{X}$. campestris is useful industrially, as producer of xanthan gum. Consequently, the $\mathrm{Lac}^{+}$engineered strains, could be used for polysaccharide production from whey, the lactose- rich by-product of milk processing (Fu \& Tseng, 1990; Papoutsopoulou et al.,1994; Drahovská \& Turna, 1995).

Considering the relevance of the E.coli lac genes, outlined above, we thought it would be useful to derive a plasmid probe that would allow evaluation of the behavior of the E.coli lac module in heterologous microbial systems and in a context of genetic variation, gene expression and assessment of potential new applications. Consequently, our aim was to clone the E.coli lac genes in a wide host range, conjugative plasmid vehicle to generate a plasmid probe that would allow transmission of the lac genes to a wide variety of microorganisms. To achieve this objective we used pULB113 (Van Gijsegem \& Toussaint, 1982), a plasmid vector for in vivo cloning that has been useful in generating molecular clones in several microbial systems, owing to its capacity for horizontal transmission, conferred in turn, by its wide host range, typical of replicons belonging to the IncPa incompatibility group (Van Gijsegem \& Toussaint, 1982; Chatterjee et al., 1985).

\section{MATERIALS AND METHODS}

\section{1.- Bacterial strains, plasmids and phages}

Table 1. shows a list of bacteria, plasmids and phages used in this work. Additional bacterial strains are described in the Results section.

\section{2.- Culture media, microbial growth and characte- rization tests}

All bacterial strains were grown routinely in LB broth or agar (1\% Tryptone, $0.5 \%$ Yeast Extract, $0.5 \%$ $\mathrm{NaCl}$ and $1.5 \%$ Agar for solid medium). MacConkey Agar Base was used to determine fermentation of sugars added at $1 \%$ final concentration. Medium M9 (Miller, 1972) was used as minimal growth medium. Culture media and components were from Difco (Detroit, Michigan) and salts for media and buffers from Merck (Darmstadt, Germany). For marine bacteria, $3 \% \mathrm{NaCl}$ was used in culture media.

For phenotypic characterization tests and the preparation of selective plates used in genetic crosses, antibiotics (Sigma, St. Louis. Mo., unless otherwise indicated) were used in the following concentrations, in $\mu \mathrm{g} / \mathrm{ml}$ : ampicillin (Ap, 25), tetracycline (Tc, 25), kanamycin $(\mathrm{Km}, 50)$, chloramphenicol $(\mathrm{Cm}, 20)$, streptomycin $(\mathrm{Sm}, 200)$, nalidixic acid (Nal, 100) and rifampicin (Rif, 100; P-L Biochemicals, Milwaukee, Wis.).

Arabinose (Ara, Pfanstiehl, Waukegan, Ill.) and lactose (Lac, NBC, Cleveland,Ohio) were used in fermentation tests and the latter also as carbon source in M9 medium.

\section{3.- Assay of $\beta$-galactosidase activity}

The qualitative and quantitative assays of $B$ galactosidase were performed according to the the standard methodology described by Miller (1972), using suspensions of toluenized cells and ortho-nitrophenylthio-galactoside (ONPG, Sigma) as enzyme susbstrate. For the induction of lac genes, iso-propyl-thio-galactoside (IPTG, Sigma) was used, as recommended by the same author.

\section{4.- Analyses of plasmid DNA}

Preparation of plasmid DNA was according to 
Kado \& Liu (1981), except that bacterial cells were initially suspended in sterile, deionized water. Cell lysis was for one hour at $65^{\circ} \mathrm{C}$. Plasmid DNA was resolved by horizontal gel electrophoresis in $0.4 \%$ agarose prepared in Tris-Borate-EDTA buffer, $\mathrm{pH} 8$.

The gel was stained in ethidium bromide, viewed under UV light and photographed according to Sambrook et al. (1989).

\section{5.- Genetic crosses and phage assays}

For the construction of pUCV3 and bacterial strains with different plasmids (see Results), conjugative genetic crosses were performed by the spin mating technique. We used exponentially growing cultures, in LB broth at a density of approximately $1 \times 10^{8} \mathrm{cells} / \mathrm{ml}$. Equal volumes $(0.5 \mathrm{ml})$ of donor and recipient populations were mixed together in sterile $1.5 \mathrm{ml}$ Eppendorf tubes and spun for 1 minute in an Eppendorf Model $5+1+$ microcentrifuge. Tubes were then incubated for $24 \mathrm{~h}$ at $28^{\circ} \mathrm{C}$ without discarding the supernatant. Cells were then resuspended by vortexing and $0.1 \mathrm{ml}$ samples of the mating mixture seeded on selective plates for the recovery of transconjugants. Separate cultures of donors and recipients, treated similarly. served as controls.

Phage susceptibility or resistance of bacterial strains was determined by cross-streak. using exponentially growing cultures of bacteria and freshly prepared cell-free lysates of GU5 and Mu cts 62.

\section{RESULTS AND DISCUSSION}

Our main objective was to obtain a plasmid probe containing the E.coli lac genes. such that it could be transmitted to a wide varicty of microorganisms and thereby allow evaluation of basic issucs concerning lac gene expression in heterologous genetic backgrounds. Likewise, potential new applications of the lac system could be visualized and explored.

To achicve our goal. we used the in vivo cloning vector pULB1 13. This is a plasmid of the IncPa incompatibility group. a set of wide host range replicons, characterized by their ability to flow among different genera of Proteobacteria and to transfer as well. to other phy logenetic groups (for reviews. see Thomas. 1989). pULBI 13. in particular, is a derivative of RPt containing a Mu.3A insertion. itself a transposable genetic module derived from phage Mu (Van Gijscgem \& Toussaint. 1982). In fact. Mu3A is a defective phage capable only of transposition. since it docs not code for any viral protcins. Therefore. pULB113 codes for the pattern of antibiotic resistance conferred by RP4 ( Ap. Tc. Km ) and acts as a vector for the delivery of Mu3A. Thus, upon entrance of pULB113 into bacterial cells, Mu3A can transpose to many different sites in the chromosome of the recipient, adjacent to corresponding chromosomal loci such as the lac operon, thereby generating regions of homology with pULB1 13, such that integrative recombination is possible. In this way, the following genetic configuration is likely to arise: lac-Mu3A-RP4-Mu3A. A further translocation of Mu3A to the left of lac is feasible, creating a new region of homology that allow's recombination with the distal copy of Mu3A so that a new plasmid is reconstituted in the form of an R-prime factor, carrying the lac genes that have been cloned in vivo (see Van Gijsegem \& Toussaint, 1982, for further details).

In our experiments to derive pUCV3, we crossed E. coli MxR with $E$. coli VAL53 selecting transconjugants in MacConkey Agar plates containing $\mathrm{Cm}, \mathrm{Ap}, \mathrm{Km}$ and Tc. The resulting strain, $\boldsymbol{E}$. coli VAL55, is $\mathrm{Lac}^{+}$and resistant to all the specified antibiotics. VAL 55 was then grown to saturation to allow the in vivo generation of recombinant plasmids that were outcrossed to $\boldsymbol{E}$. coli 2908. Transconjugants containing pULB1 13 derivatives with cloned lac genes were selected on M9-lactose plates containing Sm at a frequency of about $2 \times 10^{-6}$ transconjugants/donor cell. One of these transconjugants. designated VAL 102 and containing the recombinant plasmid pUCV 3 was used in further experiments.

Figure 1 shows that . in fact. pUCV3 contains cloned genetic material from VAL 55. since its molecular mass is incremented in relation to the parental vector molcculc pULB113. In addition. and according to phenotypic analyses shown in Table 1, pUCV3 contains the lac system genes. as it confers a $\mathrm{Lac}^{+}$phenotype on strain VAL 102. complementing the lac deletion of the parcntal $E$. coli strain 2908 . It also confers the same pattern of resistance to antibiotics as pULB 113 and a pattern of GU5 and Mu cts62 susceptibility that is the inverse of that shown by strain 29()8. This was expected because VAL 102 should express P type pili and immunity to phage Mu owing. respectively, to the tra functions coded in pUCV3 and the copies of Mu3A that form part of its genetic structure. A similar situation is observed for VAL 55 with respect to VAL 53. We should also point out that pUCV 3 complements the lac Y mutation. affecting the lactose permease in the E.coli strain $\mathrm{C}(0)($ ) (Nal-r). In fact. E.coli $\mathrm{C} 6(0)$ transconjugants containing pUCV 3 which were the product of a cross with Val 1(12. all exhibited a Lac phenotype on MacConkey agar plates. All these analyses. taken together with the fact that the cloned lac genes are inducible by IPTG (Table 3). indicate that pUCV.3 contains the complete version of the E.coli lac. operon. These results confirm the relative ease of manipulation of the pULB 13 cloning system in $\boldsymbol{E}$. coli as in other Gram negative bacteria (Van Gijsegem \& 
TABLE 1. Bacterial strains, plasmids and phages.

\begin{tabular}{|c|c|c|}
\hline Biologicals & Relevant features & Source \\
\hline \multicolumn{3}{|l|}{ Bacteria } \\
\hline $\begin{array}{l}\text { Escherichia coli } \mathrm{K}-12 \\
\mathrm{M} \times \mathrm{R}\end{array}$ & $\begin{array}{l}\text { lac genes deleted. Lac } \\
\text { Contains pULB } 113\end{array}$ & F. V. Gijsegem \\
\hline VAL 53 & $\begin{array}{l}\text { Prototrophic. } \\
\text { Contains Tn9 in chromosome. } \\
\text { Cm-r }\end{array}$ & This work \\
\hline VAL 55 & $\begin{array}{l}\text { Same as VAL } 53 . \\
\text { Contains pULB } 113\end{array}$ & This work \\
\hline 2908 & $\begin{array}{l}\text { Arabinose sensitive. Rec- } \\
\text { lac genes deleted.Sm-r. }\end{array}$ & R. Curtiss \\
\hline VAL 102 & $\begin{array}{l}\text { Same as } 2908 . \\
\text { Contains pUCV3 }\end{array}$ & This work \\
\hline \multicolumn{3}{|l|}{ Plasmids } \\
\hline pULB 113 & $\begin{array}{l}\mathrm{RP} 4:: \mathrm{Mu} 3 \mathrm{~A} \text {. Confers resistance } \\
\text { to Ap, Tc and } \mathrm{Km}\end{array}$ & F.V. Gijsegem \\
\hline pUCV 3 & $\begin{array}{l}\text { In vivo cloning product of } \\
\text { lac genes from } \boldsymbol{E} \text {. coli. Confers } \\
\text { resistance to Ap, Tc, Km and } \\
\text { Lac+ phenotype }\end{array}$ & This work \\
\hline \multicolumn{3}{|l|}{ Phages } \\
\hline GU5 & Phage specífic for P-type pili & F.V.Gijsegem \\
\hline Mucts62 & $\begin{array}{l}\text { Derivative of phage } \mathrm{Mu} \text { with } \\
\text { thermosensitive repressor }\end{array}$ & R. Hull \\
\hline
\end{tabular}

Toussaint, 1982; Chaterjee et al., 1985).

We should also mention that in our experiments we recovered other genetic markers by cloning in pULB113: for example, genes for arabinose utilization, that conferred an Ara-r phenotype on E.coli 2908 (data not shown).

We were also interested in probing transmission of
pUCV3 to other microbial groups to evaluate expression of the $E$. coli lac genes in other genetic backgrounds, through the assay of $\beta$-galactosidase activity coded by the lacZ gene. For this purpose, VAL 102 was crossed with Rif-r derivatives of the marine bacteria Vibrio harveyi and BM-E and the gliding bacterium Cytophaga johnsonae. 
TABLE 2: Phenotypes conferred by pULB 113 and pUCV 3 on strains of $E$. coli.

\begin{tabular}{|l|ccccccccc|}
\hline \multicolumn{10}{|c|}{ Tests } \\
\hline Strains & Lac & Ara & Ap (25) & Tc(25) & Km(50) & Rec & GU5 & Mu & ONPG \\
\hline 2908 & - & $\mathrm{S}$ & $\mathrm{S}$ & $\mathrm{S}$ & $\mathrm{S}$ & - & $\mathrm{R}$ & $\mathrm{S}$ & - \\
VAL 102 & + & $\mathrm{S}$ & $\mathrm{R}$ & $\mathrm{R}$ & $\mathrm{R}$ & - & $\mathrm{S}$ & $\mathrm{R}$ & + \\
VAL 53 & + & $\mathrm{R}$ & $\mathrm{S}$ & $\mathrm{S}$ & $\mathrm{S}$ & + & $\mathrm{R}$ & $\mathrm{S}$ & + \\
VAL 55 & + & $\mathrm{R}$ & $\mathrm{R}$ & $\mathrm{R}$ & $\mathrm{R}$ & + & $\mathrm{S}$ & $\mathrm{R}$ & + \\
\hline
\end{tabular}

Positive test $(+)$ and negative $(-) \mathrm{R}=$ resistant and $\mathrm{S}=$ sensitive.

TABLE 3: Expression of $\beta$-galactosidase coded by pUCV3 in various bacterial hosts.

\begin{tabular}{|c|c|c|c|c|}
\hline \multirow[t]{2}{*}{ Bacterial strain (a) } & \multirow[t]{2}{*}{ Plasmid content } & \multicolumn{2}{|c|}{$\begin{array}{l}\text { Relative activity of } \\
\boldsymbol{\beta} \text {-galactosidase (b) }\end{array}$} & \multirow[t]{2}{*}{$\begin{array}{l}\text { Growth in MS } \\
\text { lactose (c) }\end{array}$} \\
\hline & & + IPTG & - IPTG & \\
\hline $\begin{array}{r}\text { E. coli } \mathrm{K}-12 \\
\mathrm{M} \times \mathrm{R} \\
2908\end{array}$ & $\begin{array}{l}\text { pULB } 113 \\
\text { None } \\
\text { pULB } 113 \\
\text { pUCV } 3\end{array}$ & $\begin{array}{l}<1 \\
<1 \\
<1 \\
100\end{array}$ & $\begin{array}{l}<1 \\
<1 \\
<1 \\
1.8\end{array}$ & $\begin{array}{l}\text { NO } \\
\text { NO } \\
\text { NO } \\
\text { YES }\end{array}$ \\
\hline Vibrio harveyi BB7-1 & $\begin{array}{c}\text { None } \\
\text { pULB } 113 \\
\text { pUCV } 3\end{array}$ & $\begin{array}{c}<1 \\
<1 \\
113.3\end{array}$ & $\begin{array}{l}<1 \\
<1 \\
10\end{array}$ & $\begin{array}{l}\text { NO } \\
\text { NO } \\
\text { YES }\end{array}$ \\
\hline BM-E & $\begin{array}{l}\text { pULB } 113 \\
\text { pUCV } 3\end{array}$ & $\begin{array}{c}<1 \\
115.1\end{array}$ & $\begin{array}{l}<1 \\
<1\end{array}$ & $\begin{array}{l}\text { NO } \\
\text { YES }\end{array}$ \\
\hline $\begin{array}{c}\text { Cytophaga johnsonae } \\
\text { UW101 }\end{array}$ & $\begin{array}{c}\text { None } \\
\text { pULB } 113 \\
\text { pUCV } 3\end{array}$ & $\begin{array}{l}\text { ND } \\
\text { ND } \\
\text { ND }\end{array}$ & $\begin{array}{l}\text { ND } \\
\text { ND } \\
\text { ND }\end{array}$ & $\begin{array}{l}\text { NO } \\
\text { NO } \\
\text { YES }\end{array}$ \\
\hline
\end{tabular}

(a) V. harveyi BB7-1 (obtained from M. Silverman) and BM-E (isolated in our laboratory) are both marine bacteria. C. johnsonae UW 101, is a gliding, soil bacterium obtained from J. Pate.

(b) Activity of $\beta$-galactosidase in E.coli Val 102 was given the value of $100 \%$, in relation to which the activities in other strains were expressed.

(c) Media for the growth of marine bacteria contained $3 \% \mathrm{NaCl}$. 
Analyses of $\beta$-galactosidase activities in pUCV3 and pULB113 transconjugants of these bacterial strains together with enzyme activity in the corresponding parental bacteria are shown in Table 3 . We note the fact that the E.coli lac genes are fully functional in the marine bacteria tested, which show activities over the $\boldsymbol{E}$. coli control and maintenance of the system's repression and inducibility by IPTG. This is confirmed by the fact that these bacteria are capable of growth on lactose as sole source of carbon and energy. This genetic compatibility could be understood in terms that E.coli and marine bacteria such as $\boldsymbol{V}$. harveyi and BM-E belong to the same phylogenetic group of Proteobacteria. However, we also observed that the lac system allows growth of $C$.johnsonae in M9-lactose , in spite of the fact that this bacterium belongs to another phylogenetic group, distant from the Proteobacteria. In this case, we did not determine $\beta$ galactosidase activity, because $C$. johnsonae cells produce a yellow pigment that inter-feres with readings of the product of ONPG hydrolysis, itself of yellow color. Nevertheless, the pUCV 3 resistance markers were present in the corresponding $C$. johnsonae derivative, although we could not detect plasmid DNA in this strain. It is possible that it had integrated in the $C$. johnsonae chromosome, in a manner analogous to what has been described for Myxococcusxanthus, a gliding bacterium in which chromosomal integration of the plasmid RP4 has been shown, following conjugation with $\boldsymbol{E}$.coli (Breton et al., 1985). An interesing alternative to consider would be that pULB113 had integrated into the $C$. johnsonae chromosome by homologous recombination with a transposed copy of Mu3A. To prove this point would be worthwhile since there are no data on the behavior of $\mathrm{Mu}$ or Mu-like phage in gliding bacteria of the Cytophaga group.

The data in Table 3 suggest that pUCV3, or derivatives thereof containing specific mutations in the $E$ coli lac operon could be used to explore aspects of variation and expression of that genetic module in other bacteria, in a vein similar to that reported for Agrobacterium by Bezdek \& Soska (1984) and for Proteus by Roberts \& Baumberg (1984). However, the pULB113 system offers the advantage of avoiding the more cumbersome derivation of in vitro-generated constructs.

Another further use of pUCV3 could be concieved within the context of conjugative transmission of genes from bacteria to the yeast Saccharomyces cerevisiae (Heinemann \& Sprague, 1989). In fact, replicons such as pUCV3 could be used for the transmission of bacterial genes into yeast cells to study their behavior in an eukaryotic background. There is already a report concerning these studies, in which wide host range bacterial plasmids of other incompatibility groups were used to test gene transfer from $\boldsymbol{E}$. coli to the yeast

\section{Figure 1}

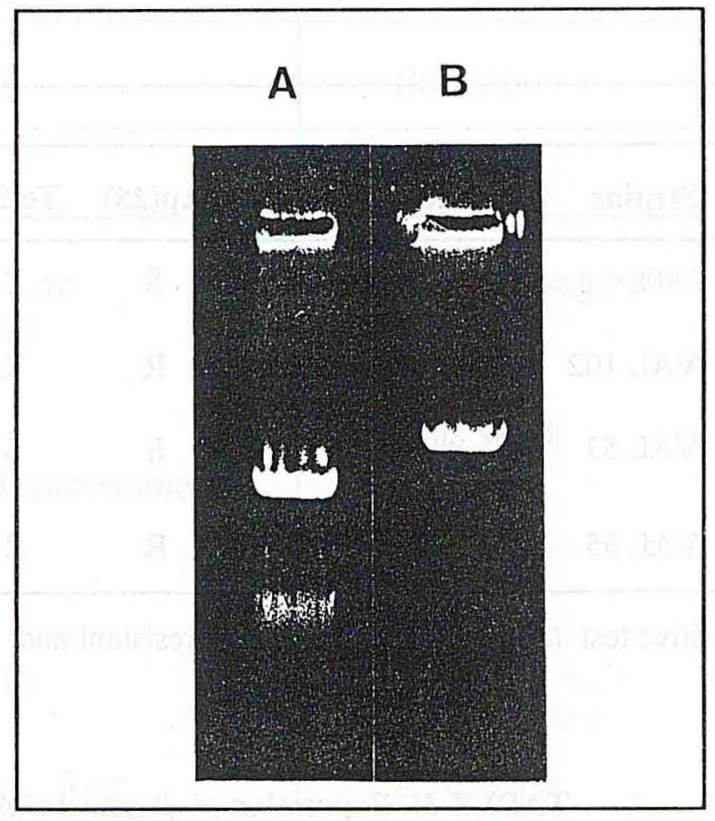

Photograph under UV light of an agarose gel $(0.4 \%$ in TBE buffer, $\mathrm{pH} 8.0)$, stained with ethidium bromide ( 0.5 $\mathrm{mg} / \mathrm{ml}$ ), in which plasmid bands are seen, corresponding to pULB113 (lane A) and pUCV3 (lane B). The latter shows an increase in molecular mass in relation to the parental plasmid. Diffuse bands under plasmid DNA correspond to chromosomal DNA fragments. DNA in A was prepared from $E$. coli $\mathrm{MxR}$ and that in B from $E$. coli Val 102.

Saccharomyceskluyveri (Inomata et al.,1994). In addition, given the recognized suitability of yeast for industrial fermentation processes, it is of interest to project the specific design of novel yeast strains for applied purposes, using both eukaryotic and prokaryotic genes as raw materials. Evidence for this line of activity is available in the work of Compagno et al. (1995), who tailored yeast strains for the utilization of whey and starch, and that of Adam et al. (1995) who designed a strain of $\boldsymbol{S}$. cerevisiae for the production of a bacterial $\beta$-glucosidase.

In summary, we have constructed a plasmid vehicle for the lateral transmission of E.coli lac genes, that allows evaluation of the behavior of this genetic system in other microbial backgrounds.

\section{ACKNOWLEDGEMENTS}

To the Dirección General de Investigación y Postgrado, Universidad Católica de Valparaíso, for financial support and to Ms. Annelene Heim for collaboration in typing the manuscript. 


\section{REFERENCES}

Adam, A.C.; Rubiotexeira, M.; Polaina, J. (1995).Induced expression of b-glucosidase activity in Saccharomyces. Yeast 11:395-406

Bender, J. \& Kleckner, N. (1986). Genetic evidence that 'Tn10 transposes by a non-replicative mechanism. Cell 45: 801-815

Bezdek, M. \& Soska, J. (1984). Interspecific transfer of the Escherichin coli lactose operon using the transposon Tn3 and plasmid R772 and its expression in Agrobacterium tumefaciens. FEMS Microbiol. Lett. 25:14.

Breton, A.M.; Jaoua, S.; Guespin-Michel, J. (1985). Transfer of plasmid RP4 to Myxococcus xanthus and evidence for its integration into the chromosome. J. Bacteriol. 161: 523-528

Cairns, J.; Overbaugh, J.; Miller, S. (1988). The origin of mutants. Nature 335: 142-145

Calos, M.P.; Lebkowski, J.S.; Botchan, M.R. (1983). High mutation frequency in DNA transfected into mammalian cells. Proc. Natl. Acad. Sci., 80: 3015-3019

Chatterjee, A.K.; Ross, L.M.; McEvoy, J.L.; Thurn, K.K. (1985). pULB113, an RP4:mini-Mu plasmid, mediates chromosomal mobilization and R-prime formation in Erwinia amylovora, Erwinia chrysanthemi. and subspecies of Erwinia carotovora. Appl. Environ. Microbiol. 50: 1-9

Compagno,C.; Porro, D.; Sme raldi, C.; Ramzi, B.MI.(1995). Fermentation of whey and starch by transformed Saccharomyces cerevisiae cells. Appl. Microbiol. \& Biotechnol. 43: 822-825

Davies, C.M.; Apte, S.C.; Peterson, S.M. (1995). b-D-galactosidase activity of viable, non-culturable coliform bacteria in marine waters. Lett. Appl. Microbiol. 21:99-102

Drahovska, H. \& Turna, J. (1995). Constrùction of lactose- utilizing Xanthomonas campestris with a mini-Mu derivative. Appl. Environ. Microbiol. 61: 811-812

Eisenstadt, E. (1987). Analysis of mutagenesis. In: Escherichia coli and Salmonella typhimurium Cellular and Molecular Biology (ed. F.C. Neidhardt). American Socicty for Microbiology. W'ashington,D.C.pp. 10161033

Fu, J-F.\& Tseng, Y-H. (1990)). Construction of lactose - utilizing Xanthomonas campestris and production of xanthan gum from whey. Appl. Environ. Microbiol. 56: 919-923

Galitski, T. \& Roth, J. (1996). A search for a general phenomenon of adaptive mutability. Genetics 143: 645-659

Heinemann, J.A. \& Sprague, G.F. (1989). Bacterial conjugative plasmids mobilize DNA between bacteria and yeast. Nature 34(): 205-209

Inomata, K.; Nishikawa, M.; Yoshida, K. (1994). The yeast
Saccharomyces kluyveri as a recipient eukaryote in transkingdom conjugation: behavior of transmitted plasmids in transconjugants. J. Bacteriol. 176: 4770-4773

Jacob, F. \& Monod, J. (1961). Genetic regulatory mechanisms in the synthesis of proteins. J. Mol. Biol. 3: 318-356

Kado, C.I. \& Liu, S.-T. (1981). Rapid procedure for detection and isolation of large and small plasmids. J. Bacteriol. 145: 1365-1373

Kleina, L.G.; Masson, J.M.; Normanly, J.; Abelson, J.; Miller, J.H. (1990). Construction of Escherichia coli amber suppressor tRNA genes II. Synthesis of additional tRNA genes and improvement of suppressor efficiency. J. Mol. Biol. 231: 705-717

Miller, J.H. (1972). "Experiments in Molecular Genetics". Cold Spring Harbor Laboratory Press, New York.

\& Albertini, A.M. (1983). Effects of surrounding sequence on the suppression of nonsense codons. J. Mol. Biol. 164: 59-71

Nghiem, Y.; Cabrera, M.; Cupples, C.G.; Miller, J.H. (1988). The $m u t Y$ gene: a mutator locus in Escherichia coli that generates G.C-T.A transversions. Proc. Natl. Acad. Sci. 85: 2709-2713

Nwoguh, C.E.; Harwood, C.R.; Barer, M.R. (1995). Detection of induced b-galactosidase activity in individual non-culturable cells of pathogenic bacteria by quantitative cytological assay. Mol. Microbiol. 17; 545-554.

Papoutsopoulou, S.V.; Ekateriniadou, L.V.; Kyriakidis, D.A.(1994). Genetic construction of Xanthomonas campestris xanthan gum production from whey. Biotechnol. Lett. 16: 1235-1240

Roberts, M. \& Baumberg, S. (1984). Anomalous expression of the E. coli lac operon in Proteus mirabilis. I. Effects of L8 and L8UV5. Mol. Gen. Genet. 198: 159-165

Sambrook, J.; Fritsch, E.F.; Maniatis, T. (1989). Molecular cloning. A laboratory manual. Cold Spring Harbor Laboratory Press, New York.

Slauch, J.MI. \& Silhavy, T.J. (1991). Genetic fusions as experimental tools. Methods Enzymol. 204: 213-248

Sniegowski, P.D. \& Lenski, R.E. (1995). Mutation and adaptation: the directed mutation controversy in evolutionary perspective. Annu. Rev. Ecol. Syst. 26: $553-578$

Thomas, C.M. (ed.). 1989. “Promiscuous plasmids of Gram negative bacteria“. Academic Press. New York.

Van Gijsegem, F. \& Toussaint, A. (1982). Chromosome transfer and Rprime formation by an RP4::mini-Mu derivative in Escherichia coli. Salmonella typhimurium, Klebsiellapneumoniae, and Proteus mirabilis. Plasmid 7: 30-44 